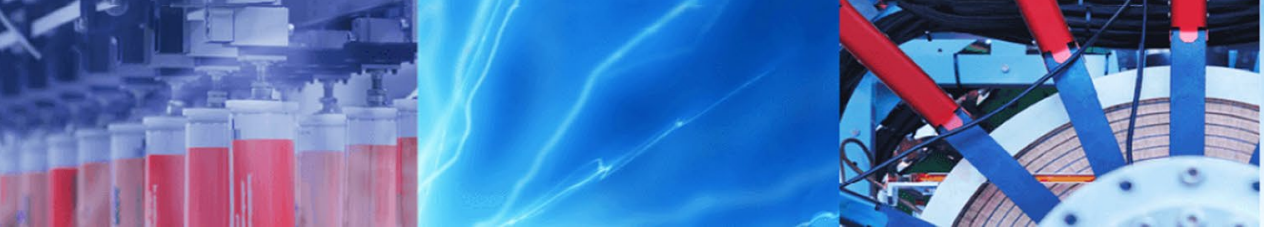

Review Paper

\title{
Studies on the titanium dioxide nanoparticles: biosynthesis, applications and remediation
}

\author{
Meghmala S. Waghmode ${ }^{1} \cdot$ Aparna B. Gunjal ${ }^{2}$. Javed A. Mulla ${ }^{1} \cdot$ Neha N. Patil $^{1} \cdot$ Neelu N. Nawani $^{3}$
}

(c) Springer Nature Switzerland AG 2019

\begin{abstract}
Nanoparticles have wide applications in various fields due to their small size. Titanium dioxide nanoparticles are bright with high refractive index $(n=2.4)$ which makes them suitable for industry dealing with toothpaste, pharmaceuticals, coatings, papers, inks, plastics, food products, cosmetics and textile. Three crystalline phases of titanium dioxide, are anatase (tetragonal), rutile (tetragonal), and brookite (orthorhombic) in which brookite has no commercial value. Due to their self cleaning and antifogging property, they are used in the preparation of cloths, windows, tiles and anti-fogging car mirrors. Titanium dioxide nanoparticles also serve as environment sanitizing agent. Sol-gel route, flame hydrolysis, co-precipitation, impregnation and chemical vapor deposition like techniques are used for the synthesis of $\mathrm{TiO}_{2}$ nanoparticles. Biosynthesis of titanium dioxide nanoparticles has gained wide interest among researchers due to its cost effective, eco-friendly and reproducible approach. The sol-gel route remediation of the titanium dioxide from the environment is an important step and it can be achieved by using physical processes like sedimentation and filtration. The biosynthesis of titanium dioxide nanoparticles can be used in comparison to chemical synthesis. The titanium dioxide nanoparticles have wide applications, viz., reducing toxicity of dyes and pharmaceutical drugs; waste water treatment; reproduction of silkworm; space applications; food industries; etc., and so have immense industrial importance. The applications of nanoparticles synthesized by biological approach will be advantageous for the industries; environment and agriculture.
\end{abstract}

Keywords Sedimentation · Filtration · Antifogging $\cdot$ Refractive index $\cdot$ Titanium dioxide nanoparticles

\section{Introduction}

India is the reservoir of two chief minerals of titanium viz., Ilmenite $(\mathrm{FeO} . \mathrm{TiO} 2)$ and rutile $\left(\mathrm{TiO}_{2}\right)$. Titanium dioxide $\left(\mathrm{TiO}_{2}\right)$ exists in rutile, anatase (octahedrite) and brookite form. Brookite is not found in abundance, it is an altered product of some titanium minerals. The reservoirs of $\mathrm{TiO}_{2}$ in different states are shown in Table 1. The $\mathrm{TiO}_{2}$ nanoparticles have many merits viz., high specific-surface area, proper electronic band structure, high quantum efficiency, chemical innerness and stability [1]. The research is gaining immense interest for the synthesis of $\mathrm{TiO}_{2}$ on a largescale by biological way which will be cost-effective.
There is report on $\mathrm{TiO}_{2}$ nanoparticles synthesized using microbes viz., Lactobacillus sp. and Sachharomyces cerevisae which is low-cost [3, 4]; using Aspergillus flavus TFR7 [5, 6], Chromohalobacter salexigens strain PMT-1 [7]. There is a report on biologically synthesized of $\mathrm{TiO}_{2}$ nanoparticles using Bacillus subtilis (FJ460362) for the study of photo catalytic activity in controlling aquatic biofilm [8]. Nanoparticles have wide applications specially the $\mathrm{TiO}_{2}$ particles viz., cosmaceutical, pharmaceutical, optical, commercial applications [9].

There are reports on applications of $\mathrm{TiO}_{2}$ nanoparticles. Cyanide annual world production is 1.4 million tons and is mainly used for gold mining. But, most of the cyanide from

\footnotetext{
$\triangle$ Aparna B. Gunjal, aparnavsi@yahoo.com | ${ }^{1}$ Department of Microbiology, Annasaheb Magar Mahavidyalaya, Hadapsar, Pune, Maharashtra, India. ${ }^{2}$ Asian Agri Food Consultancy Services Ltd, Pune, Maharashtra, India. ${ }^{3}$ Dr. D.Y. Patil's Vidyapeeth Dr. D.Y. Patil Biotechnology \& Bioinformatics Institute, Tathawade, Pune, Maharashtra, India.
} 
Table 1 Reservoirs of $\mathrm{TiO}_{2}$. Source: (Indian Minerals Yearbook [2]

\begin{tabular}{lcc}
\hline States of India & $\begin{array}{l}\text { Resources of ilmen- } \\
\text { ite minerals (million } \\
\text { tonnes) }\end{array}$ & $\begin{array}{l}\text { Resources of rutile } \\
\text { minerals (million } \\
\text { tonnes) }\end{array}$ \\
\hline Odisha & 96.44 & 4.47 \\
Tamil Nadu & 179.02 & 8.00 \\
West Bengal & 2.05 & 0.19 \\
Andhra Pradesh & 163.05 & 10.25 \\
Jharkhand/Bihar & 0.73 & 0.01 \\
Gujarat & 2.77 & 0.02 \\
Kerala & 145.70 & 8.41 \\
Maharashtra & 3.74 & 23.00 \\
\hline
\end{tabular}

the industry enters the environment and is very toxic. There are various approaches to remove cyanide which is time consuming and costly. Photo catalytic properties of titanium dioxide nanoparticles helps in removal of cyanide from the waste water using the hydrolysis technique [10]. Similarly, there is a report where $\mathrm{TiO}_{2}$-activated carbon composites have application in photo catalytic degradation of $\beta$-naphthol from the waste water [11]. The photo catalytic behavior of $\mathrm{TiO}_{2}$ has been studied for the degradation of beta-naphthol using $x$-ray diffraction and TEM [12].

There are many methods of the synthesis of $\mathrm{TiO}_{2}$ nanoparticles viz., sol-gel technique, solvothermal, hydrothermal, electrochemical process, precipitation method; etc. But they have disadvantages e.g. sol-gel takes hours to days for the formation of $\mathrm{TiO}_{2}$ nanoparticles; hydrothermal method is synthetic method and involves chemical reactions; precipitation method involves difficulty in control of particle size as fast precipitation causes formation of larger particles. Microbial nanoparticle synthesis based method is eco-friendly and cheap as it get operated under mild conditions.

The nanotechnology is gaining immense importance and the researchers are focusing for the new applications of nanoparticles in industries; agriculture; pharmaceuticals; etc. There is a need to study large scale biosynthesis of $\mathrm{TiO}_{2}$ nanoparticles and their applications in unexplored fields.

The novelty of the review here is it mentions specifically the synthesis and applications of $\mathrm{TiO}_{2}$ nanoparticles. Although, there are research papers on $\mathrm{TiO}_{2}$ nanoparticles, but still more work needs to done and the review gives the detail idea of various applications of $\mathrm{TiO}_{2}$ nanoparticles which can be the scope for further research studies on $\mathrm{TiO}_{2}$ nanoparticles.

With this view, the objective of the review here is to focus on the aspects of biosynthesis of $\mathrm{TiO}_{2}$ nanoparticles and also their utility in pharmaceutical, construction, textile, food industries; etc. The applications of $\mathrm{TiO}_{2}$ nanoparticles in aerospace; solar cells and agriculture is also described. The review also highlights the application of $\mathrm{TiO}_{2}$ nanoparticles in waste water treatment dependent on the photo catalytic behavior. The remediation and recycling of $\mathrm{TiO}_{2}$ is also mentioned in the review.

\section{Biosynthesis of $\mathrm{TiO}_{2}$ nanoparticles}

Living systems are involved in the production of nanoparticles which are more stable as compared with chemically synthesized nanoparticles. Nanoparticles synthesized using microorganisms are found to have less aggregation behavior due to presence of more repulsive forces. Utility of nanoparticles is mainly dependent upon its size, shape as well as stability. Hence, researchers focus on the biogenic synthesis of nanoparticles which can fulfill the criteria. $\mathrm{TiO}_{2}$ nanoparticles which naturally exists in three different crystalline forms anatase, rutile and brookite can be produced using biological agent. Extensive research is carried on the biosynthesis of nanoparticles. Biosynthesis of nanoparticles is one of the growing areas in the field of nanotechnology. Various reports are available on the utilization of bacteria, fungi, algae, plant material and enzymes for the biosynthesis of nanoparticles. The mechanisms involved in the microbial synthesis of nanoparticles are bio absorption, extracellular complexation or precipitation of metals, bioaccumulation, efflux systems, and alteration of solubility and toxicity via reduction or oxidation and lack of specific metal transport systems [13]. Negative electrokinetic potential, bio sorption and bio reduction ability of the microorganisms makes them suitable candidate to synthesize nanoparticles $[3,4]$. There is information on synthesis of $\mathrm{TiO}_{2}$ nanoparticles using fungal pathogen Fusarium oxysporium. Saccharomyces cerevisiae and Lactobacillus sp. have been reported to produce 30 and $18 \mathrm{~nm}$ $\mathrm{TiO}_{2}$ nanoparticles using $\mathrm{TiO}(\mathrm{OH})_{2}$. Energy source, $\mathrm{pH}$ and overall oxidation reduction potential were found to be important factors in the synthesis of $\mathrm{TiO}_{2}$ nanoparticles, while in the case of Saccharomyces cerevisiae, oxidase enzyme plays an important role $[3,4] . \mathrm{TiO}_{2}$ nanoparticles in anatase form were synthesized using Curcuma longa plant extract due to its content of terpenoids, flavonoids and proteins [14]. Fenugreek (Trigonella foenum graecum (L.)) has been studied to synthesize $\mathrm{TiO}_{2}$ nanoparticles with antimicrobial property [15]. There is a report on the synthesis of rutile $\mathrm{TiO}_{2}$ nanoparticles using custard apple peel extract and precursor TiO $(\mathrm{OH})_{2}$ [16]. The presence of $\mathrm{OH}$ group in the chemical constituents of Annona squamosa was found to be responsible to dehydrate titanyl hydroxide to $\mathrm{TiO}_{2}$ and stabilize the nanoparticles [16]. $\mathrm{TiO}_{2}$ nanoparticles produced using Vigna radiata (green gram) 
legumes showed antibacterial, antioxidant and cytotoxicity activity against Mg 63 osteosarcoma cell lines [17]. Titanium dioxide nanoparticles due to Lactobacillus crispatus has been found to reduce biofilm formation; hemolysin and also urease which are responsible to develop multidrug resistance ability in the pathogens [18]. Electrostatic interaction between Lactobacillus sp. and metal clusters are responsible for the metal nanoparticles synthesis [19]. The production of anatase $\mathrm{TiO}_{2}$ nanoparticles mediated by Bacillus subtilis has been studied [20].

Guava (Psidium guajava) leaf extract mediated $\mathrm{TiO}_{2}$ nanoparticles showed antioxidant and antimicrobial activities [21]. Guava leaf extract contains alcohol, primary and aromatic amines which assists in the synthesis of $\mathrm{TiO}_{2}$ nanoparticles [21]. $\mathrm{TiO}_{2}$ nanoparticles made by using Aspergillus flavus TFR7 and bulk $\mathrm{TiO}_{2}$, was used as foliar spray (10 mg/l) on mung bean (Vigna radiata L.). This fungal mediated $\mathrm{TiO}_{2}$ found to enhance the vigor index of mung bean [5, 6]. Fungi secrete capping proteins which play the role of encapsulation of nanoparticles while associated proteins contributes in the mineralization of precursor salt $[22,23]$. Aspergillus niger and Aspergillus tubingensis TFR-5 have also been reported to have the capability to produce $\mathrm{TiO}_{2}$ nanoparticles $[24,25]$.

\section{Application of titanium dioxide nanoparticles}

The applications of titanium dioxide nanoparticles are shown in Fig. 1.

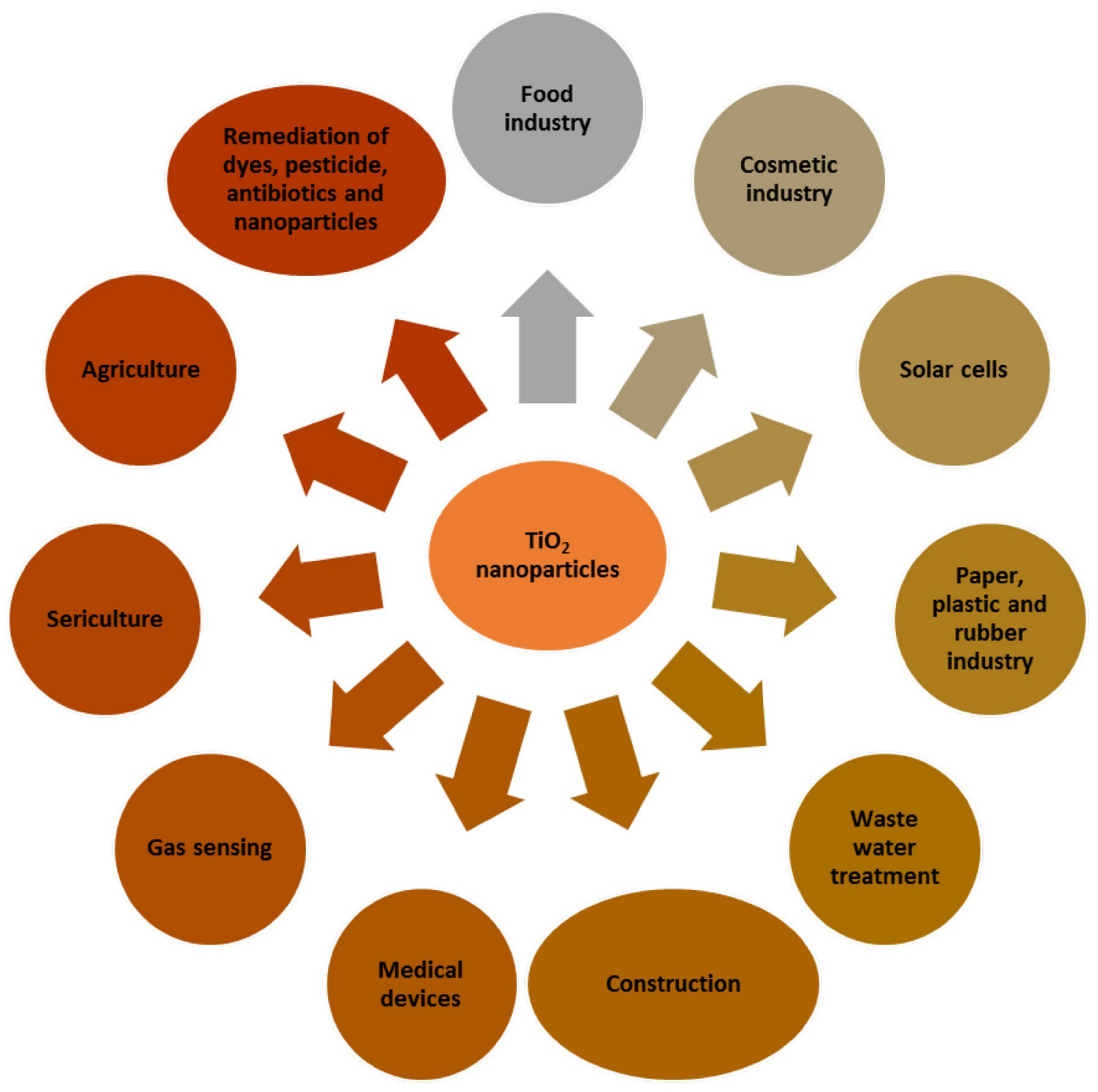

Fig. 1 Applications of $\mathrm{TiO}_{2}$ nanoparticles 


\subsection{Industrial applications of titanium dioxide nanoparticles}

$\mathrm{TiO}_{2}$ nanoparticles have wide applications in industry; some of them are given in Table 2.

\subsection{Role of $\mathrm{TiO}_{2}$ nanoparticles in reducing toxicity of dyes and pharmaceutical drugs}

$\mathrm{TiO}_{2}$ work as a nanocatalyst in the degradation of methyl orange dye. $\mathrm{TiO}_{2}$ nanoparticles synthesized using Citrus paradisi peel extract exhibited $72 \%$ degradation of methyl orange using sunlight [37]. Antiseptic commonly used in pharmaceutical industry chlorhexidine digluconate (CHD) affects aquatic environment by inducing resistance in microorganisms and also affects human health. Using optimum conditions of UV light intensity of $50 \mu \mathrm{W} \mathrm{cm}$, $\mathrm{pH} 10.5,2.5: 1$ of substrate-to-catalyst ratio $68.2 \%$ degradation of chlorhexidine digluconate (CHD) was achieved using titanium dioxide as a photo catalyst. In future, it is possible to reduce the toxic effects of waste water generated from pharmaceutical industry [38]. Researchers tried nanocomposites for the removal of antibiotics from the environment. $\mathrm{G}-\mathrm{TiO}_{2}$ composites were found to have $97 \%$ removal efficiency of levofloxacin (for $1 \mathrm{mg} / \mathrm{l}$ ) using $300 \mathrm{~W}$ UV power and 45 min irradiation time [39]. Use of $\mathrm{TiO}_{2}$ as a sorbent is limited due to its low surface area which is able to remove contaminants in low concentration. To reduce its agglomeration ability and to increase its surface area along with photo catalytic activity, $\mathrm{TiO}_{2}$ has been supported on zeolite, alumina, activated carbon and stainless steel. Composites of $\mathrm{TiO}_{2}$ with coconut shell powder were prepared using sol-gel method with heat treatment. These composites were reported to remove $98 \%$ carbamazepine, antiepileptic drug which is an important organic pollutant [40].

Table 2 Industrial applications of $\mathrm{TiO}_{2}$ nanoparticles

\begin{tabular}{ll}
\hline Uses of $\mathrm{TiO}_{2}$ nanoparticles & References \\
\hline Cosmetics & {$[26,27]$} \\
Dye sensitized solar cells & {$[28]$} \\
Paper, plastic and rubber industry & {$[29]$} \\
Food additive & {$[30]$} \\
Construction material & {$[31]$} \\
Coating to building & {$[32]$} \\
Pigment & {$[33]$} \\
Medical devices & {$[34]$} \\
Gas sensing & {$[35]$} \\
Sunscreens & {$[36]$} \\
\hline
\end{tabular}

$\mathrm{TiO}_{2}$ nanoparticles can be used for the photo degradation of toxic dyes and other pharmaceutical drugs, thus avoid harmful effects on environment.

\section{3 $\mathrm{TiO}_{2}$ nanoparticles in the reproduction of silk worm}

It has been reported that low concentrations of $\mathrm{TiO}_{2}$ nanoparticles shows significant changes in the reproduction rate of Bombyx mori. There is a report where feeding Bombyx mori with $\mathrm{TiO}_{2}$ nanoparticles resulted in a rapid development of sex organs and up regulation of reproductionrelated genes [41]. After feeding of Bombyx mori average increase was found to be 51 eggs/insect and $0.34 \times 10^{-4}$ g/egg [41].

Reproduction efficiency of silkworm can be increased by mixing low concentration of $\mathrm{TiO}_{2}$ nanoparticles in their feed.

\subsection{Waste water treatment}

Low cost, resistance to corrosion and overall stability makes $\mathrm{TiO}_{2}$ nanoparticles suitable for the waste water treatment [42]. Remediation of surface water can be achieved using $\mathrm{TiO}_{2}$ nanoparticles as solid phase extraction (SPE) packing material to preconcentrate and extraction of heavy metals from water [43]. Ultraviolet light and titanium dioxide $\left(\mathrm{TiO}_{2}\right)$ nanoparticles doped with iron showed $98.58 \%$ diazinon removal efficiency, diazinon is one of organophosphate pesticides which it is classified as a relatively dangerous substance (Class II by World Health Organization), found in ground water [44]. Decolorization of waste water is the primary treatment considered in waste water treatment. Dyes like Rhodamine $B$, methylene blue and malachite green are primary dyes found in the effluent. Dye Rhodamine B is found to degrade up to $95 \%$ due to hybrid system combining $\mathrm{UV} / \mathrm{TiO}_{2}$ nanoparticles and polyvinylidene fluoride (PVDF) membrane [45].

$\mathrm{TiO}_{2}$ nanoparticles play important role in the removal of the xenobiotic compounds like pesticides; dyes; toxic compounds from the waste water, thus having wide application in waste water treatment.

\subsection{Role of $\mathrm{TiO}_{2}$ nanoparticles in agriculture}

According to the report given by $\mathrm{Chao}$ and $\mathrm{Choi}, \mathrm{TiO}_{2}$ nanoparticles increases the photosynthetic rate, immunity of the plant which results in 30\% increase in the crop yield [46]. Increased photosynthetic rate was observed in spinach [47]. Zea mays sprayed with nano $\mathrm{TiO}_{2}$ in the reproductive stages of the crop was found to have more pigmentation [48] which is responsible to increase crop yield [49]. $\mathrm{TiO}_{2}$ nanoparticles can be applied either as soil 
amendment or foliar spray. The nanoparticles get bio distributed through the vascular network. Distribution of nanoparticles is varying among crops. In case of tomato plants, application of $\mathrm{TiO}_{2}$ nanoparticles in aerosol format was found to be more effective to increase photosynthesis and lycopene content as compared with $\mathrm{TiO}_{2}$ nanoparticles as soil amendment $[5,6]$.

$\mathrm{TiO}_{2}$ nanoparticles can be used to speed the photosynthetic rate of various crops and also enhance the crop yield.

\subsubsection{Use of $\mathrm{TiO}_{2}$ nanoparticles in nanomedicine}

$\mathrm{TiO}_{2}$ nanoparticles are used in nanotherapeutics [50]; photodynamic therapy (PDT) [51] and for articulating prosthetic implants [52]. $\mathrm{TiO}_{2}$ nanoparticles are also used in cosmetics and in treatment of hyper pigmented skin and other nondermatologic diseases [53].

$\mathrm{TiO}_{2}$ nanoparticles due to their special physical properties have useful applications in nanomedicine.

\subsection{In purification of air}

Titanium dioxide $\left(\mathrm{TiO}_{2}\right)$ photo catalyst could oxidize and mineralize compounds in the vapor or liquid phase. Hence, researchers created various filters to get rid of the indoor pollutants. Cigarette smoke (principal indoor air pollutant) can be removed by $\mathrm{TiO}_{2}$-impregnated titanium mesh filter (TMiP) by electrochemical anodization of the titanium mesh, and dip coating into $\mathrm{TiO}_{2}$ anatase solution. This filters can remove volatile and nonvolatile compounds of cigarette smoke like ammonium, nicotine, 3-ethenylpyridine and tar [54]. $\mathrm{TiO}_{2}$ has been employed in Japan as photochemical deodorizer [55]. When $\mathrm{TiO}_{2}$ nanoparticles are stimulated by sunlight, they convert the pollutants and oxides to environmental less toxic products like carbon dioxide and calcium nitrate. Volatile organic compounds (VOC) pose various adverse effects on the health. Toluene is one of the VOC which can be decomposed by coating activated carbon with $\mathrm{TiO}_{2}$ [56].

The oxidation of indoor air pollutants by $\mathrm{TiO}_{2}$ nanoparticles helps in the purification of air, which is very important for all the living beings.

\subsection{Use of photo catalytic nano $\mathrm{TiO}_{2}$ for photo catalyst coating}

A film of photo catalytic titanium dioxide is a super oxidative, hydrophilic and antistatic material used for selfcleaning of buildings. The film also oxidizes the hydrocarbon emitted as automotive exhaust and rain water washes the dirt and helps the building exterior to remain clean. Nano $\mathrm{TiO}_{2}$ photo catalyst coating will act as an invisible film and can be applied on ceiling, floor carpets, curtains, car interior, toilet seats etc. Due to this nano $\mathrm{TiO}_{2}$ film, the microorganisms can be removed. $\mathrm{TiO}_{2}$ nanoparticles are used in the anti-fogging car mirrors [57].

The photocatalytic film of $\mathrm{TiO}_{2}$ can help to keep the buildings clean.

\section{8 $\mathrm{TiO}_{2}$ nanoparticles in treatment of osteosarcoma and chonrosarcoma}

Osteosarcoma and chondrosarcoma are malignant bone tumors found in patients of all ages. Surgical amputation of the malignant lesion is generally carried out. Recently, it has been shown that $\mathrm{TiO}_{2}$ nanoparticles kill HeLa cells via photo catalysis in vitro [58]. This indicates the $\mathrm{TiO}_{2}$ nanoparticles induces cytotoxicity to bone tumor cells which will be helpful in minimization of the recurrence of osteosarcoma and chondrosarcoma.

The $\mathrm{TiO}_{2}$ nanoparticles can be used to treat the bone tumors, thus having application in the medical field.

\subsection{For dye-sensitized solar cells}

$\mathrm{TiO}_{2}$ nanoparticles have applications as semiconductor for dye-sensitized solar cells because it is non-toxic, easily available and cheap [59].

$\mathrm{TiO}_{2}$ nanoparticles have photovoltaic effect and therefore used in solar cells.

\section{$3.10 \mathrm{TiO}_{2}$ in food products}

Food products containing $\mathrm{TiO}_{2}$ include white-colored sauces, confectioneries nondairy creamers and cheese. In foods, it restores whiteness of creamy products (e.g. salad dressings) and in confectionery; it forms a blockade for colors (e.g. soft-centered sweets with a crisp shell). India sets the limit on the use of $\mathrm{TiO}_{2}$ nanoparticles up to $1 \%$ $(\mathrm{w} / \mathrm{w})$ in chewing gum and $0.01 \%(\mathrm{w} / \mathrm{w})$ in beverages (Food Safety and Standards India [60].

$\mathrm{TiO}_{2}$ nanoparticles has applications in food industries.

\subsection{Remediation of nanoparticles}

$\mathrm{TiO}_{2}$ nanoparticles have the potential to work as tracer of nanoparticles of similar size and aggregate likeTiO ${ }_{2}$ [61].

\section{Maintenance of historical architecture}

Various historically important forts and monuments get dirty over the period of time. Maintenance of cultural heritage from getting dirty is the primary requisite. Strategies applied for the consolidation of restoration 
materials include application of alkaline earth metal hydroxide nanoparticles or nanostructured $\mathrm{SiO}_{2}, \mathrm{Al}_{2} \mathrm{O}_{3}$, $\mathrm{TiO}_{2}$ in low and high molecular weight matrices [62, 63]. Self cleaning, depolluting and biocide activity of titania makes them suitable to use in the construction or maintenance of stone surfaces [64]. Photo catalytic activity of $\mathrm{TiO}_{2}$ nanoparticles can exist in the presence of UV light to modify these $\mathrm{TiO}_{2}$ nanoparticles to retain anatase form and photo catalytic potential in the presence of sunlight also. To retain the potential of $\mathrm{TiO}_{2}$ nanoparticles, various approaches like synthesis of $\mathrm{TiO}_{2}$ in benzyl alcohol, water and ethylene glycol dispersions of benzyl-capped anatase nanoparticles have been studied for the retention of photocatalytic activity in presence of sunlight [65]. Spray coating of $\mathrm{TiO}_{2}$ nanoparticles as colloidal suspension on travertine limestone found to be effective to maintain the stone surface [64]. Water and ethylene glycol dispersions of benzyl-capped anatase nanoparticles of $\mathrm{TiO}_{2}$ were applied onto Noto stone and Carrara marble specimens found to retain photo catalytic activity [65].

The photo catalytic potential of $\mathrm{TiO}_{2}$ nanoparticles is very important for the maintenance of historical monuments.

\subsection{Titanium for aerospace industry}

The application of titanium alloys in the aerospace sector includes airframe, engine, helicopter, and space applications. Light weight, high strength, compatibility with CFRP and external corrosion resistance of titanium and its alloys enables them to be used in aircraft [66]. Broad research has been carried out on the preparation of titanium alloys like, Ti-6Al-4V at low cost and its use in aerospace industry. Titanium alloys have an excellent strength-to-weight ratio.

$\mathrm{TiO}_{2}$ nanoparticles has application in the making of aircraft and aircraft engines.

\subsection{Toxic effects of $\mathrm{TiO}_{2}$ on human}

Information is available on the toxic effects of $\mathrm{TiO}_{2}$ on human as they can bio concentrate, bio accumulate, and bio magnify in the tissues of mammals and other vertebrates [67]. Microparticles of $\mathrm{TiO}_{2}$ get accumulated in macrophages of human gut-associated lymphoid tissue [68]. There is a report on the in silico study of $\mathrm{TiO}_{2}$ spherical nanoparticles using twenty standard amino acids in aqueous solution [69]. Basic amino acids tend to have direct interaction with $\mathrm{TiO}_{2}$, while acidic amino acids have indirect interaction with $\mathrm{TiO}_{2}$ spherical nanoparticles [69].

\subsection{Toxic effects of $\mathrm{TiO}_{2}$ on ecosystem}

Wide use of $\mathrm{TiO}_{2}$ nanoparticles in personal care products viz., shaving creams $(<0.01 \mu \mathrm{g} / \mathrm{mg})$, toothpastes and sunscreens ( $1 \%$ to $>10 \%$ titanium by weight), foods and household products leads to its release through human excreta, washed off of surfaces, or disposed of to sewage that enters wastewater treatment plants and in bio solids which will be further applied to soil as fertilizer. As per report on WWTP, raw sewage contained 100 to nearly $3000 \mu \mathrm{g} \mathrm{Ti} / \mathrm{l}$ [61]. Treated effluent was found to contain $\mathrm{TiO}_{2}$ particles with 4 and $30 \mathrm{~nm}$ particle size [30]. After waste water treatment, effluent was found to contain from less than $5 \mu \mathrm{g}$ up to $15 \mu \mathrm{g}$ of nano- $\mathrm{TiO}_{2} / \mathrm{I}$ [61]. Presence of $\mathrm{TiO}_{2}$ nanoparticles into the environment affects phytoplankton and coastal ecosystems that support fishing and recreational activities. Algae are primarily used as biological marker in aquatic system to study biological toxicity of pollutants. $\mathrm{TiO}_{2}$ nanoparticles inhibit algae by causing membrane structure deformation due to increased lipid peroxidation [70]. $\mathrm{TiO}_{2}$ nanoparticles exhibit more cellular toxicity in anatase due to increased amount of intracellular reactive oxygen species (ROS) [71]. The nano bio interfacial interaction of anatase $\mathrm{TiO}_{2}$-NPs with EPS of algae showed higher algal toxicity than that of rutile $\mathrm{TiO}_{2}-\mathrm{NPs}$ [71]. Growth rate of freshwater green algae predominant in North America viz., Scenedesmus quadricauda, Chlamydomonas moewusii and Chlorella vulgaris, was found to be inhibited due to the presence of $\mathrm{TiO}_{2}$ nanoparticles in freshwater microcosms [72]. Combination of anatase and rutile showed more toxicity and antagonistic effect on freshwater algae Chlorella [73].

\subsection{Recycling of $\mathrm{TiO}_{2}$}

Disposal of sludge is very important to avoid its sequential effects. Land filling is one of the methods which are primarily used. But leaching of the heavy metals into the environment limits its use. Another alternative to land filling is restoration or recycling of the sludge. It is possible to prepare $\mathrm{TiO}_{2}$ nanoparticles using sludge. Treatment of the sludge with coagulant $\mathrm{TiCl}_{4}$ and aiding chemicals like $\mathrm{Al}_{2}\left(\mathrm{SO}_{4}\right)_{3}, \mathrm{FeCl}_{3}$ and $\mathrm{Ca}(\mathrm{OH})_{2}$, resulting flocculated sludge after incineration at $600{ }^{\circ} \mathrm{C}$ yield $\mathrm{TiO}_{2}$ doped with $\mathrm{Fe}, \mathrm{Al}$ and $\mathrm{Ca}$ [74].

\section{Conclusion}

Broad spectrum use of titanium dioxide nanoparticles has gained attention among researchers. Extensive research is ongoing on the chemical and biological synthesis of nanoparticles. Rutile $\mathrm{TiO}_{2}$ pigment is generally preferred 
for the materials which is exposed to outdoor conditions like paints, plastics and inks due to its high resistance to UV light. Anatase $\mathrm{TiO}_{2}$ pigment is the choice for paper, ceramics, rubber and fibers manufacturing industries due to its less abrasive power [75]. Biogenic synthesis is the method of choice due to its cost effectiveness, reproducibility and less time requirement. Microorganisms and plant extracts are used for the biosynthesis of $\mathrm{TiO}_{2}$ nanoparticles. Compared to microorganisms, plant extracts are more feasible to use for nanoparticles synthesis due to less requirement of aseptic conditions [21]. Plants contain flavonoids, citric acid, ascorbic acids, reductases, dehydrogenase and external electron shuttlers which makes them suitable for the nanoparticles synthesis [76]. Biogenic synthesis of nanoparticles requires alcohol, amines, enzymes and proteins for the stabilization and reduction of precursor salts. Titanium can be applied as foliar spray and found to have significant effect on growth, photosynthesis rate and carbohydrate synthesis $[5,6]$. $\mathrm{TiO}_{2}$ can sustain in the environment for long period and its antimicrobial activity makes them strong disinfectant which will be 3 times stronger than chlorine, and 1.5 times stronger than ozone. Air purifiers containing $\mathrm{TiO}_{2}$ avoid smoke, pollen, virus, bacteria and harmful gas and grab the free bacteria present in the air by filtering percentage of $99.9 \%$ due to the highly oxidizing effect of photo catalyst $\left(\mathrm{TiO}_{2}\right)$. Protection of lamp houses, walls in tunneling and white tents from becoming sooty and dark, can be achieved due to the self-cleaning and high photo catalytic potential of $\mathrm{TiO}_{2}$.

\section{Compliance with ethical standards}

Conflict of interest On behalf of all authors, the corresponding author states that there is no conflict of interest.

\section{References}

1. Lai Y, Wang L, Liu D, Chen Z, Lin C (2015) $\mathrm{TiO}_{2}$-based nanomaterials: design, synthesis and applications. J Nanomater 2015:1-3

2. Indian Minerals Yearbook, Part- III: Mineral Reviews (2013) 52nd edn

3. Jha A, Prasad K, Kulkarni A (2009) Synthesis of $\mathrm{TiO}_{2}$ nanoparticles using microorganisms. Coll Surf B: Biointerfaces 71:226-229

4. Jha A, Prasad K, Kulkarni A (2009) Synthesis of $\mathrm{TiO}_{2}$ nanoparticles using microorganisms. Colloids Surf B 71:226-229

5. Raliya R, Biswas P, Tarafdar J (2015) $\mathrm{TiO}_{2}$ nanoparticle biosynthesis and its physiological effect on mung bean (Vigna radiataL.). Biotechnol Rep 5:22-26

6. Raliya R, Nair R, Chavalmane S, Wang W, Biswas P (2015) Mechanistic evaluation of translocation and physiological impact of titanium dioxide and zinc oxide nanoparticles on the tomato (Solanum lycopersicum L.) plant. Metallomics 7:1584-1594

7. Tharanya P, Vadakkan K, Hemapriya J, Kannan V, Vijayanand S (2015) Biogenic approach for the synthesis of titanium dioxide nanoparticles using a halophilic bacterial isolate- Chromohalobacter salexigens strain PMT-1. Int J Curr Res Acad Rev 3:334-342

8. Dhandapani P, Maruthamuthu S, Rajagopal G (2012) Bio-mediated synthesis of $\mathrm{TiO}_{2}$ nanoparticles and its photocatalytic effect on aquatic biofilm. J Phytochem Photobiol 110:43-49

9. Banerjee K, Thiagarajan P (2014) A review of titanium dioxide nanoparticles-synthesis, applications and toxicity concerns. Nanosci Nanotechnol Asia 4:132-143

10. Ijadpanah-Saravi H, Safari M, Khodadadi-Darban A, Rezaei A (2014) Synthesis of titanium dioxide nanoparticles for photocatalytic degradation of cyanide in waste water. Anal Lett 47:1772-1782

11. Ijadpanah-Saravy H, Dehestaniathar Khodadadi A, Safari $M$ (2016) Optimization of photocatalytic degradation of $\beta$-naphthol using nano $\mathrm{TiO}_{2}$-activated carbon composite. Desalin Water Treat 57:4708-4719

12. Ijadpanah-Saravi H, Sarafi M, Noruzi-Masir B, Darban AK, Bakhshi P (2017) Intelligent tools to model photo-catalytic degradation of titanium dioxide nanoparticles. J Chemom 31:e2907-e2909

13. Beveridge TJ, Hughes MN, Lee H, Leung KT, Poole RK, Savvaidis I (1997) Metal-microbe interactions: contemporary approaches. Adv Microb Physiol 38:177-243

14. Abdul R, Nuaman R, Abd A (2016) Biological synthesis of titanium dioxide nanoparticles by Curcuma longa plant extract and study its biological properties. World Sci News 49:204-222

15. Subhapriya, Gomathipriya (2018) Green synthesis of titaniumdioxide $\left(\mathrm{TiO}_{2}\right)$ nanoparticles by Trigonella foenum-graecum extract and its antimicrobial properties. Microb Pathog 116:215-220

16. Roopan SM, Bharathi A, Prabhakarn A, Rahuman A, Velayutham K, Rajakumar G (2012) Efficient phytosynthesis and structural characterization of rutile $\mathrm{TiO}_{2}$ nanoparticles using Annona squamosa peel extract. Spectrochim Acta A Mol Biomol Spectrosc 98:86-90

17. Chatterjee N, Yang J, Atluri R, Lee W, Hong J, Choi J (2016) Amorphous silica nanopaticle-induced perturbation of cholesterol homeostasis as a function of surface area highlights safe-bydesign implementation: an integrated multi-OMICS analysis. RSC Adv 6:68606-68614

18. Ibrahem KH, Salman JA, Ali FA (2014) Effect of titanium nanoparticles biosynthesis by Lactobacillus crispatus on urease, hemolysin and biofilm forming by some bacteria causing recurrent UTI in Iraqi women. Eur Sci J 10:324-338

19. Nair B, PradeepT (2002) Coalescence of nanoclusters and formation of submicron crystallites assisted by Lactobacillus strains. Cryst Growth Des 2:293-298

20. Kirthi AV, Rahuman AA, Rajakumar G, Marimuthu S, Santhoshkumar T, Jayaseelan C, Elango G, Zahir A, Kamaraj C, Bagavan A (2011) Biosynthesis of titanium dioxide nanoparticles using bacterium Bacillus subtilis. Mater Lett 65:2745-2747

21. Santosh M, Sirin C, Philipp S, Andreas H, Carsten S, Marialore S (2016) The role of halide ions in the anisotropic growth of gold nanoparticles: a microscopic, atomistic perspective. Phys Chem Chem Phys 18:13246-13254

22. Raliya R, Tarafdar J (2012) Novel approach for silver nanoparticle synthesis using Aspergillus terreus CZR-1: mechanism perspective. J Bionanosci 6:12-16

23. Raliya R, Rathore I, Tarafdar J (2013) Development of microbial nanofactory for zinc, magnesium, and titanium nanoparticles production using soil fungi. J Bionanosci 7:590-596

24. Durairaj B, Muthu S, Xavier T (2015) Antimicrobial activity of Aspergillus niger synthesized titanium dioxide nanoparticles. Adv Appl Sci Res 6:45-48

25. Tarafdar A, Raliya R, Wei-Ning W, Pratim B, Tarafdar J (2013) Green synthesis of $\mathrm{TiO}_{2}$ nanoparticle using Aspergillus tubingensis. Adv Sci Eng Med 5:943-949 
26. Wolf R, Matz H, Orion E, Lipozencic J (2003) Sunscreens-the ultimate cosmetic. Acta Dermatovenerol Croat 11:158-162

27. Shi H, Magaye R, Castranova V, Zhao J (2013) Titanium dioxide nanoparticles: a review of current toxicological data. Part Fibre Toxicol 10:1-33

28. Fan J, Li Z, Zhou W, Miao Y, Zhang Y, Hu J, Shao S (2014) Dyesensitized solar cells based on $\mathrm{TiO}_{2}$ nanoparticles/nanobelts double layered film with improved photovoltaic performance. Appl Surf Sci 319:75-82

29. Zhang W, Zhu Z, Cheng C (2011) A literature review of titanium metallurgical processes. Hydrometallurgy 108:177-188

30. Weir A, Westerhoff P, Fabricius L, Hristovski K, von Goetz N (2012) Titanium dioxide nanoparticles in food and personal care products. Environ Sci Technol 46:2242-2250

31. Guo S, Wu Z, Zhao W (2009) $\mathrm{TiO}_{2}$-based building materials: above and beyond traditional applications. Chin Sci Bull 54:1137-1142

32. Mills A, Hodgen S, Lee $S$ (2005) Self-cleaning titania films: an overview of direct, lateral and remote photo-oxidation processes. Res Chem Intermed 31:295-308

33. Feldman C (2001) Preparation of nano scale pigment particles. Adv Mater 13:1301-1303

34. Visai L, de Nardo L, Punta C, Melone L, Cigada A, Imbriani M, Arciola C (2011) Titanium oxide antibacterial surfaces in biomedical devices. Int J Artif Organs 34:929-946

35. Fergus JW (2003) Doping and defect association in oxides for use in oxygen sensors. J Mater Sci 38:4259-4270

36. Trouiller B, Reliene R, Westbrook A, Solaimani P, Schiestl RH (2009) Titanium dioxide nanoparticles induce DNA damage and genetic instability in vivo in mice. Cancer Res 69:8784-8789

37. Kumar B, Cumbal L (2014) Light harvesting titanium nanocatalyst for remediation of methyl orange. Int J Chem Mol Nucl Mater Metall Eng 8:196-199

38. Das R, Sarkar S, Chakraborty S, Choi H, Bhattacharjee C (2014) Remediation of antiseptic components in wastewater by photocatalysis using $\mathrm{TiO}_{2}$ nanoparticles. Ind Eng Chem Res 53:3012-3020

39. Alicanoglu P, Sponza D (2017) Photodegradation of levofloxacin antibiotic via graphene/ $\mathrm{TiO}_{2}$ and its reusability. Int J Waste Resour 3(Suppl):7

40. Khraisheh M, Kim J, Campos L, Al-Muhtaseb A, Walker G, AlGhouti M (2013) Removal of carbamazepine from water by a novel $\mathrm{TiO}_{2}$-coconut shell powder/Uv process: composite preparation and photocatalytic activity. Environ Eng Sci 30:515-526

41. Ni M, Li F, Wang B, Xu K, Zhang H, Hu J, Tian J, Shen W, Li B (2015) Effect of $\mathrm{TiO}_{2}$ nanoparticles on the reproduction of silkworm. Biol Trace Elem Res 164:106-113

42. Theron J, Walker J, Cloete T (2008) Nanotechnology and water treatment: applications and emerging opportunities. Crit Rev Microbiol 34:43-69

43. Quetel C, Vassileva E, Petrov I, Chakarova K, Hadjiivanov K (2010) First results on Fe solid-phase extraction from coastal seawater using anatase $\mathrm{TiO}_{2}$ nano particles. Anal Bioanal Chem 396:2349-2361

44. Baneshi M, Rezaei S, Sadat A, Mousavizadeh A, Barafrashtehpour $M$, Hekmatmanesh $H$ (2017) Investigation of photocatalytic degradation of diazinon using titanium dioxide $\left(\mathrm{TiO}_{2}\right)$ nanoparticles doped with iron in the presence of ultraviolet rays from the aqueous solution. Biosci Biotech Res Comm 10:60-67

45. Vatanpour V, Karami Asma, Sheydaei Mohsen (2017) Central composite design optimization of Rhodamine $B$ degradation using $\mathrm{TiO}_{2}$ nanoparticles/UV/PVDF process in continuous submerged membrane photoreactor. Chem Eng Process: Process Intensif 116:68-75

46. Chao SL, Choi HS (2005) Method for providing enhanced photosynthesis. Korea Res Inst Chem Technol S Korea Bull 11:1-34
47. Lei Z, Mingyu S, Chao L, Liang C, Hao H, Xiao W, Xiaoqing L, Fan Y, Fengqing G, Fashui $\mathrm{H}$ (2007) Effects of nanonatase $\mathrm{TiO}_{2}$ on photosynthesis of spinach chloroplasts under different light Illumination. Biol Trace Elem Res J 119:68-76

48. Morteza E, Moaveni P, Farahani H, Kiyani M (2013) Study of photosynthetic pigments changes of maize (Zea mays L.) under nano $\mathrm{TiO}_{2}$ spraying at various growth stages. Springerplus 2:1-5

49. Yang F, Hong FS (2006) Influence of nano-anatase $\mathrm{TiO}_{2}$ on the nitrogen metabolism of growing spinach. Biol Trace Elem Res 110:179-190

50. Yuan Y, Ding J, Xu J, Deng J, Guo J (2010) $\mathrm{TiO}_{2}$ nanoparticles codoped with silver and nitrogen for antibacterial application. $J$ Nanosci Nanotechnol 10:4868-4874

51. Szacilowski K, Macyk W, Drzewiecka-Matuszek A, Brindell M, Stochel G (2005) Bioinorganic photochemistry: frontiers and mechanisms. Chem Rev 105:2647-2694

52. Jacobs JJ, Skipor AK, Black J, Urban R, Galante JO (1991) Release and excretion of metal in patients who have a total hip-replacement component made of titanium-base alloy. J Bone Joint Surg Am 73:1475-1486

53. Wiesenthal A, Hunter L, Wang S, Wickliffe J, Wilkerson M (2011) Nanoparticles: small and mighty. Int J Dermatol 50:247-254

54. Slimen H, Ochiai T, Nakata K, Murakami T, Houas A, Morito $Y$, Fujishima A (2012) Photocatalytic decomposition of cigarette smoke using a $\mathrm{TiO}_{2}$-impregnated titanium mesh filter. Ind Eng Chem Res 51:587-590

55. Fukuyama J (2004) Odor pollution control for various odor emission sources in Japan, East Asia. In: Odor measurement and control review workshop (Environmental Management Bureau, Ministry of the Environment, Government of Japan), pp 67-77

56. Rezaee A, Pourtaghi G, Khavanin A, Mamoory R, Ghaneian M, Godini H (2008) Photocatalytic decomposition of gaseous toluene by $\mathrm{TiO}_{2}$ nanoparticles coated on activated carbon. Iran J Environ Health Sci Eng 5:305-310

57. Montazer M, Seifollahzadeh S (2011) Enhanced self-cleaning, antibacterial and UV protection properties of nano $\mathrm{TiO}_{2}$ treated textile through enzymatic pretreatment. Photochem Photobiol 87:877-883

58. Sha B, Gao W, Han Y, Wang S, Wu J, Xu F, Lu T (2013) Potential application of titanium dioxide nanoparticles in the prevention of osteosarcoma and chondrosarcoma recurrence. J Nanosci Nanotechnol 13:1208-1211

59. Mbonyiryivuze A, Zongo S, Diallo A, Bertrand S, Minani E, Yadav L, Mwakikunga B, Dhlamini S, Maaza M (2015) Titanium dioxide nanoparticle biosynthesis for dye sensitized solar cells: review. Phys Mater Chem 3:12-17

60. Food Safety and Standards [FSS] India (2011) Food safety and standards (food product standards and food additives) regulation. 4:449-529

61. Kiser M, Westerhoff P, Benn T, Wang Y, Pérez-Rivera J, Hristovski K (2009) Titanium nanomaterial removal and release from wastewater treatment plants. Environ Sci Technol 43:6757-6763

62. Chelazzi D, Poggi G, Jaidar Y, Toccafondi N, Giorgi R, Baglioni P (2013) Hydroxide nanoparticles for cultural heritage: consolidation and protection of wall paintings and carbonate materials. $J$ Colloids Interf Sci 392:42-49

63. Miliani C, Velo-Simpson M, Scherer G (2007) Particle-modified consolidants: a study on the effect of particles on sol-gel properties and consolidation effectiveness. J Cult Herit 8:1-6

64. Goffredo G, Munafo P (2015) Preservation of historical stone surfaces by $\mathrm{TiO}_{2}$ nanocoatings. Coatings 5:222-231

65. Gherardi F, Colombo A, Goidanich S, Simonutti R, Toniolo L (2014) Innovative nano- $\mathrm{TiO}_{2}$ particles for self-cleaning treatments of historic architecture and sculptures. Restor Build Monum 20:423-432 
66. Inagaki I, Takechi T, Shirai Y, Ariyasu N (2013) Application and features of titanium for aerospace industry. Nippon Steel Sumitomo Met Tech Rep 396:23-28

67. Jovanovic B (2014) Critical Review of Public Health Regulations of titanium dioxide, a human food additive. Integ Environ Assess Manag 11:10-20

68. Lomer M, Thompson R, Powell J (2002) Fine and ultrafine particles of the diet: influence on the mucosal immune response and association with Crohn's disease. Proc Nutr Soc 6:123-130

69. Liu P, Jin H, Guo Z, Ma J, Zhao J, Li D, Wu H, Gu N (2016) Silver nanoparticles outperform in radiosensitizing $U 251$ cells in vitro and in an intracranial mouse model of glioma. Int Nanomed 11:5003-5014

70. Ozkaleli M, Erdem A (2018) Biotoxicity of $\mathrm{TiO}_{2}$ nanoparticles on Raphidocelis subcapitata microalgae exemplified by membrane deformation. Int J Environ Res Public Health 15:1-12

71. Gao X, Kaijun Z, Luqing Y, Daohui L (2018) Distinct effects of soluble and bound exopolymeric substances on algal bioaccumulation and toxicity of anatase and rutile $\mathrm{TiO}_{2}$ nanoparticles. Environ Sci Nano 5:720-729

72. Cardinale BJ, Bier R, Kwan C (2012) Effects of $\mathrm{TiO}_{2}$ nanoparticles on the growth and metabolism of three species of freshwater algae. J Nanopart Res 14:1-8
73. Iswarya V, Bhuvaneshwari M, Alex S, lyer S, Chaudhuri G, Chandrasekaran P, Bhalerao G, Chakravarty S, Raichur A, Chandrasekaran N, Mukherjee A (2015) Combined toxicity of two crystalline phases (anatase and rutile) of titania nanoparticles towards freshwater microalgae: Chlorella sp. Aquat Toxicol 161:154-169

74. Shon H, Vigneswaran S, In Kim, Cho J, Kim GJ, Kim JB, Kim JH (2007) Preparation of titanium dioxide $\left(\mathrm{TiO}_{2}\right)$ from sludge produced by titanium tetrachloride $\left(\mathrm{TiCl}_{4}\right)$ flocculation of wastewater. Environ Sci Technol 41:1372-1377

75. Gazquez M, Bolívar J, Garcia-Tenorio R, Vaca F (2014) A Review of the production cycle of titanium dioxide pigment. Mater Sci Appl 5:441-458

76. Pandey S, Oza G, Mewada A, Sharon M (2012) Green synthesis of highly stable gold nanoparticles using Momordica charantia as nano fabricator. Arch Appl Sci Res 4:1135-1141

Publisher's Note Springer Nature remains neutral with regard to jurisdictional claims in published maps and institutional affiliations. 